\title{
CONTROVERSIES AND OPPORTUNITIES OF TWO DEVELOPMENT MEASURES FOR THE ADVANCEMENT OF WOMEN IN UGANDA: FORMAL EDUCATION AND FEMALE ENTREPRENEURSHIP
}

\author{
OLGA MARGRET MARIA NAMASEMBE
}

Institute for Gender and Women's Studies

Faculty of Social Sciences and Humanities, University of Granada

Calle Rector López Argüeta s/n 18071 Granada, Spain

Email address: olgalivale@gmail.com

ORCID: https://orcid.org/0000-0002-4084-7770

ROSER MANZANERA RUIZ

Department of Sociology

Faculty of Political Science and Sociology, University of Granada

Calle Rector López Argüeta s/n 18071 Granada, Spain

Email address: roser@ugr.es

ORCID: https://orcid.org/0000-0001-9020-8371

\begin{abstract}
Aim. The aim of the research is to investigate the relationship between formal education and female entrepreneurship in Uganda. This research hopes to contribute to the literature on education and women's entrepreneurship in this country.

Methods. Data is collected from 109 women through semi structured interviews. These are participants from the agribusiness sector and own businesses ranging from market stalls, retail shops to street businesses. Through the iterative process, emerging themes are analysed and discussed.

Results. The research finds that formal education programmes and macroeconomic policies negatively impact formal education and female entrepreneurship. Macroeconomic policies such as privatisation and the programmes of universal formal education do not incentivise students (specifically female ones) to pursue a full formal education, influencing them to leave schools early for necessity entrepreneurship to meet immediate needs.

Conclusions. Even though the study indicates that a formal education demonstrates high outcomes in terms of economic growth and development, the education level attained by women entrepreneurs is insufficient to meet true entrepreneurial success. Furthermore, the macroeconomic environment adds to the challenge of successful women entrepreneurship.
\end{abstract}


Originality. Various economic initiatives have been implemented in the quest for gender parity in education and women empowerment in Uganda since its independence. Statistics have demonstrated an increase in women's education and empowerment through entrepreneurship, however, such data do not necessarily reflect economic development. The results suggest that the relationship between formal education and women entrepreneurship is more complex and nuanced than previously believed.

Key words: formal education, macroeconomic policies, education programmes, women entrepreneurship, Uganda

\section{INTRODUCTION}

$\mathrm{T}$ The measures for the promotion of women in education and in the productive sector of the economy through business creation have been two fundamental measures in the search for greater equality between men and women in the world of development, especially beginning with the Beijing Conference in 1995. The promotion of formal education for girls and programs to promote women's entrepreneurship are considered some of the most important strategies aimed at poverty alleviation by African governments and United Nations agencies (United Nations, 2000) and are main ways aimed at improving economic growth and development in Uganda (Blaak, Openjuru, \& Zeleen, 2013; Namukwaya \& Kibirige, 2019).

Formal education is structured and intentional learning delivered by qualified teachers with the purpose of developing students' ability to think for themselves, learn the discipline and difference between good and evil, share different perspectives on topics with classmates, as well as be able to make decisions about the changes that occur in their social, economic, and political spheres (Asongu \& Odhiambo 2018; Fitzgerald, 2020; Zembylas, 2001). Therefore, a quality formal education is necessary for female entrepreneurs who define themselves as business organisers and managers to consolidate their entrepreneurial success (Asongu \& Odhiambo, 2018). This is important because the Government of Uganda, like several African governments, is considering female entrepreneurship as a mechanism to boost economic growth and development in order to reduce poverty levels in the country (Etim \& Iwu, 2019; Panda, 2018). Proponents of formal education assert that it is the gateway to success in life given the achievements it can bring, such as prestige as a qualified professional in a society, more opportunities, social influence, and higher incomes from employment (Ahimbisibwe, 2019).

Women entrepreneurship is defined as self-employment or the creation of a business where the total or majority of the ownership and the decision-making processes are owned and managed by women respectively (Carter \& Shaw, 2006). According to the United Nations Development Program (UNDP, 2004), a woman entrepreneur is one who has started or inherited a business by herself or with one or more partners, and is eager to assume the financial and administrative risks and responsibilities, as well as participate in the daily management of operations. However, it should be noted that despite these definitions, 
women entrepreneurs face numerous prejudices and gender stereotypes that place them as passive victims with little ability to manage businesses and are considered outsiders in sectors dominated by men (Asare, Akuffobea, Quaye, \& Atta-Antwi, 2015; Etim \& Iwu, 2019).

Due to the influence of the Sustainable Development Goals in 2015, there has been a significant increase in formal education and entrepreneurship in Uganda that has brought women entrepreneurs to the forefront of entrepreneurship. The promotion of male entrepreneurship by the Ugandan government that had begun in the 1980's with macroeconomic policies such as privatisation (MasterCard Index, 2018; Tushabomwe-Kazooba, 2006) has been remodelled to include women as well. However, both formal education and women entrepreneurship have not been without criticism (Etim \& Iwu, 2019; Guma, 2015). Some of the criticisms lie in the contradictory conditions that appear when applied to the development context.

The interest in formal education and women entrepreneurship comes at a time when Uganda is grappling with the problem of business sustainability within the economy (Sejjaaka, Mindra, \& Nsereko, 2015; Struwig, Krüger, \& Nuwagaba, 2019). On the one hand, there is a significant increase of women in entrepreneurship and women literacy of $70.84 \%$ in 2018 from $61.97 \%$ in 2012, but on the other hand, there is a gap between these two development measures reflected in business failure and unemployment levels in Uganda (Odaga, 2020; Ssempebwa, 2008). A lot of research has been done about formal education and women entrepreneurship highlighting those entrepreneurs fail due to limited education. However, there is little research done that analyses the extent to which this limitation affects women entrepreneurs in particular and yet women entrepreneurship has become a mechanism for economic growth and development. In this sense, this research seeks to connect the relationships between educational programs and women entrepreneurship initiatives.

The objectives of this article are twofold: on the one hand, we present and discuss different theoretical proposals on both development measures from a feminist perspective; and on the other hand, some hypotheses are defined from previous discussions in the field research in relation to the contradictions that emerge between both measures for the promotion of women in Uganda.

\section{Formal education for girls and female entrepreneurship in Uganda}

Uganda's schools provide two methods for formal school attendance; one of them is a "boarding school" which was adopted from the British (Bamford 1967; Scanlon, 1964), where students come to school for a fixed period of time at the end of which they return home for a vacation. The other method is a "day school" where students commute from home on a daily basis to attend school for the fixed period of time (Blau \& Blau, 2019). School fees charges for "day scholars" are usually lower because they do not require sleeping facilities at school at the end of the day (Ninsiima \& Abonit, 2013). Uganda's formal schools' curriculum is subject oriented and based on subjects such as English, Mathematics, Science, and Social Studies (National Curriculum 
Development Centre [NCDC], 2020). The level of intensity increases within the recognised four levels of education which include primary, secondary, tertiary and university levels of formal education. At the end of each level a certificate or degree of accomplishment is issued (Uganda Bureau of Statistics [UBOS], 2017; Ejuu, 2012).

Despite this apparently favourable context for the population's access to formal education, there is a significant gap in the completion rate as the educational level progresses. This gap increases in the case of girls (Kayongo, Kawooya, \& Mijumbi-Deve, 2019) due to factors such as the generic division of labour in which girls, especially those who reside in rural areas, are seriously affected by their domestic responsibilities such as finding and hauling water and firewood before attending school, or the price of school fees. According to United Nations International Children's Emergency Fund (UNICEF, 2019) and United Nations Educational, Scientific and Cultural Organisation (UNESCO, 2019), there are fewer than four girls enrolled for every five boys at the secondary level. Many families have turned to informal education for their daughters in order to equip them with entrepreneurial skills (Ezati, Madanda, \& Ahikire, 2018; Kayongo et al., 2019).

Informal education for entrepreneurship for women and girls who leave the formal educational system

According to the UBOS (2017), 57\% of young people (15-24 years of age) have not reached primary education and only $28 \%$ have reached secondary education. However, the statistics show that secondary school enrolment increased from $54 \%$ for boys and $46 \%$ for girls in 2008 to $53 \%$ for boys and $47 \%$ for girls in 2014, while total enrolment in tertiary education for women increased from $38 \%$ in 2002 to $44 \%$ in 2014 . The completion rate of primary education also improved from $47 \%$ in 2008 (boys - 50\% and girls - 44\%) to $72 \%$ for both boys and girls in 2014 with the final primary exam (PLE) passed. The rate for girls increased from $65.3 \%$ in 2002 to $86.2 \%$ in 2014 .

Qualitative studies have explained that the continued disparity between formal education for boys and girls comes from multiple factors. For girls, it is the families' lack of income to pay for school fees, given the gendered nature of domestic work (Jones, 2011; Kayongo et al., 2019; Wodon et al., 2016). Additionally, the formal education system itself has been a subject of controversy in recent years, with critics arguing that it does not offer real solutions to current problems such as unemployment due to its highly theoretical format (Blaak et al., 2013; Nangoli, Turinawe, Kituyi, Kusemererwa, \& Jaaza, 2013; Orobia, Tusiime, Mwesigwa, \& Ssekiziyivu, 2020) and its lack of inclusion of all Ugandans' needs due to universalism (Bannink, Nalugya, \& van Hove, 2020). Critics have further argued that even with government's efforts to incorporate entrepreneurship education in schools (Okoth, 2019; Ratten \& Jones, 2018) in addition to initiating entrepreneurship programs targeted at women and the youth such as the Ugandan women entrepreneurship programme in 2015 and the youth livelihood programme in 2013, literacy skills attained through a quality 
formal education are necessary for economic development to be reflected in the lives of the citizens (Asongu \& Odhiambo, 2018; Gavigan, Ciprikis, \& Cooney, 2020). Formal entrepreneurship education leaves a lot to be desired given the challenges of funding, optionality and limited time allocated to it in school timetables. These challenges have made its harmonisation with other formal subjects a major difficulty (Ajagbe, Kelechi, Kimuli, \& Cho, 2016; NCDC, 2014).

It should be noted that given the challenges formal education in Uganda is facing and the increased drive toward entrepreneurship, informal education has become the alternative to the formal one. Informal education is characterised by learning from experience, from home, the social environment and from work (Kislova, 2020; Kolodych \& Zarzycka-Dertli, 2020). Informal education has been presented as the opportunity for girls in the face of economic contingencies to obtain skills and competencies from their parents, guardians, and the community, which are useful in everyday life, such as financial education that is usually helpful when it comes to business entrepreneurship (Monteith \& Camfield, 2019; Noguchi, 2018).

\section{Historical and cultural context of formal education and female entrepreneurship in Uganda \\ Pre-independence period (Buganda region)}

During the pre-colonial period $\left(11^{\text {th }}\right.$ and $12^{\text {th }}$ centuries), formal education was delivered through work (Humphris \& Lles, 2013; Khadidja, 2014). The generic separation of labour maintained a harmonious division between women and men (Musisi, 1993; Ssekamwa, 1997) in which both sexes participated in the care of farms and economic activities such as manufacturing and marketing activities for upholstery and other commodities unanimously (Matovu, 2016). The specialisation of work was communal and the education provided implied the acquisition of skills to be effective in ensuring the long-term sustainability of families (Green, 2010). This African educational system provided an environment in which both men and women worked not only for their benefit, but also for the benefit of the society as a whole (Stonehouse, 2012).

The discovery of lucrative minerals such as iron ore (Musisi, 1993) in the $14^{\text {th }}$ century led to competition for resources which gave a way for economic and social changes that caused subtle socio-economic gender differences, for example in household responsibilities. The intercostal trade in the 1800s further amplified the gender differences as it brought Arabs to Buganda in 1844. They introduced Islamic education at the king's court, which involved the study of the Quran and Arabic language (Ajayl, 1998). However, this situation did not last long as trade relations broke down when King Ssuuna II Kalema refused to convert to Islam (Oded, 1974). Thirty-three years later, in 1877, the first missionaries arrived from Great Britain to Buganda at the court of King Muteesa I (Hansen \& Twaddle, 2002; Twaddle, 1974). They used education in their evangelisation process as an instrument (Mockler-Ferryman, 1903) for implementing a new way of life. 
The British formal education in 1894 cemented the unequal relations between men and women. It was based on a Victorian gender model where women fulfilled reproductive roles through having and taking care of children and maintaining the house, a model that some authors called the domestication of women (Rogers, 1980), while men were charged with providing income for their families (Matovu, 2016; zu Selhausen, 2015). This model drastically changed the gender dynamics between men and women, as women were limited to the jobs of household responsibilities, while men were the only ones privileged to work in colonial establishments such as tea and cotton fields (Nayenga, 1981). Formal education was aimed primarily for men, as the new economy was meant for them to work in order to pay taxes (Kikooma, 2012; zu Selhausen, 2015). Therefore, the entrepreneurial spirit of women was limited and they were considered non-economic agents (Boserup, 1970), being marginalised out of school education among other economic activities (Akyeampong \& Fofack, 2014), while men were privileged in the activities that the new system introduced and that continue to this day.

\section{Government efforts to promote women in formal education since the independence}

Independence in 1962 brought changes in favour of formal education and economic participation of women (Frankema, 2012) in Uganda. Despite the masculinised approach to mission education, formal schools were created specifically for girls (Sheldon 2015; Sobehart 2009). In such schools, future teachers, nurses, and doctors were trained to occupy important positions in the government administration. They benefited from certain economic and political privileges (zu Selhausen, 2015) as many of them later occupied positions of political responsibility (Kadaga, 2013; Kyomuhendo \& McIntosh 2006).

It is known and recognised by the international community that Uganda has currently made significant efforts to strengthen and institutionalise gender equality through formal education and women entrepreneurship (National Development Plan [NDP], 2015). Furthermore, in 2015, through the Ministry of Gender, Labour and Social Development, the government launched the Uganda Women's Entrepreneurship Program (UWEP) which aims to empower women by improving their access to financial services in order to enhance business economic growth (NDP, 2015). The creation of the Uganda Ministry of Education and Sports (MoES) in 1997 was also mandated to promote female education through providing, supporting, guiding, coordinating, regulating and promoting quality education and sports for all people in Uganda for national integration, as well as individual and national development (MoES, 2015). The vision of the Ministry is to guarantee quality education and sports for all. In 2000, MoES designed a National Strategy for Girls' Education (NSGE) as a mechanism to address concerns about girls' education. For its part, the NSGE of the Ministry of Education and Sports optimally pursues the increase in the number of girls who access education, in particular primary education, and that aims to 50/50 gender parity (MoES, 2013). 


\section{METHODOLOGY AND SAMPLE SELECTION}

To analyse the relationship between formal education and women entrepreneurship, the authors of this article employed a descriptive research design to consider multiple dimensions of the participants' experiences. Data were collected from 109 women entrepreneurs owning agribusinesses from Kampala and Wakiso between July and December 2019. Primary information was derived from the women entrepreneurs through semi structured interviews. This was done face to face by the interviewer. The type of businesses selected included the following: market businesses (62), street businesses (20), retail shop businesses (18), restaurants (4), farmers (1), green house farmers (1), seed producers (1), and mobile money (2). Purposive sampling was applied (Creswell, 2012) and 109 female entrepreneurs in agribusiness were interviewed. The selection criteria for participants were based on their willingness to participate in the interviews and their residency in the study area. The first participants then recruited more respondents through snowball sampling. The contact strategy was based on approaching female entrepreneurs in the main markets which included Nakasero, Kalerwe, Ntinda and Wandegeya, as well as in retail shops and streets. Then, the study aims were explained to potential participants. The confidentiality was guaranteed at all times.

It should be noted that the research methods had a few limitations. First of all, the research tools methods did not allow long engagement with the sample population. This was because their nature of business did not allow spending much time to fully answer the questions since they had to divide their attention between the interviews and their business operations. Due to the fact that the research was conducted during Christmas months, female entrepreneurs were very busy and so it was difficult to get their undivided attention. Thus, the semi-interviews may not have been as in-depth as desired. What is more, the sampling methods may not fully represent the entire demographic of women entrepreneurs in Kampala and Wakiso. To overcome these limitations, a longitudinal study should be carried out to allow an in-depth analysis of the themes that emerge with regards to formal education and women entrepreneurship in order to allow for generalisation.

The questions were translated from English to Luganda and participants' responses were recorded in audio format in Luganda. These were complemented by note taking in English. The audio recordings were then transcribed into English and analysed. Similar themes were identified through iterative analysis with particular emphasis on the contradictions between formal education and women entrepreneurship, the impact of the macroeconomic policies on women's education and entrepreneurship and finally the challenges women face due to market liberal policies. 


\section{RESULTS AND ANALYSIS}

\section{Contradictions between equality policies in formal education} and the promotion of women through entrepreneurship

\section{Findings from the data and analysis}

While the government of Uganda has endeavoured to provide universal education programmes for its citizens, there are factors that work against proper education attainment which suggests a lack of efficiency in the universal education strategy. According to findings of this research, $11 \%$ of women entrepreneurs never went to school. $45.9 \%$ of female entrepreneurs stopped going to school at primary school level, $28.4 \%$ said that they went to school up to secondary school level, and only $14.7 \%$ had completed their university education (Table 1). The main reasons that led them to leave schools early included starting families of their own and having to work to sustain them, as well as lack of financial resources to pay the school fees. As the participants stated:

I had children to take care of who had no father and yet I had no education to ask for a job anywhere. So the circumstances pushed me to start an income generating activity. (Participant 4)

I started this market business because I had very little education. If I was educated, I would be employed somewhere else that is better, this was what I wanted in my childhood but due to school fees limitations I didn't go far. Now I work hard so that I pay school fees for my children who will graduate and get good jobs that I didn't get. (Participant 1)

Table 1

Percentages of level of formal education of women entrepreneurs

\begin{tabular}{clcc}
\hline No. & \multicolumn{1}{c}{ Variable } & Frequency & Percentage \\
\hline 1. & No education & 12 & $11.0 \%$ \\
2. & Primary school education & 50 & $45.9 \%$ \\
3. & Secondary school education & 31 & $28.4 \%$ \\
4. & University education & 16 & $14.7 \%$ \\
\hline \multicolumn{2}{c}{ Total } & 109 & $100 \%$ \\
\hline
\end{tabular}

Source: own research.

There are a multitude of implementation problems that have contradicted the success and the advancement of women with regards to formal education (Orobia et al, 2020) and women entrepreneurship. Universal school education programmes, for example, have compromised the access to and the quality of education (Blaak et al., 2013; Datzberger, 2018) that both girls and boys receive due to the increase in the classroom ratio at primary and secondary levels (UBOS, 2017). Coupled with poor teacher remuneration to enforce school discipline, this creates an environment that may result in leaving school and unplanned homemaking for women (Kayongo et al., 2019; Komakech, 2015) and thus resulting in a search for work to take care of the family hence a shift 
in goals from formal education to women entrepreneurship. This leads to the creation of small and medium sized enterprises that are survival driven with limited education experience to lead them to higher success.

Additionally, given the need to achieve the United Nations sustainable development goal of gender equality and meeting the requirements of the World Bank and the International Monetary Fund to acquire loans for development (Forster, Kentikelenis, Reinsberg, Stubbs, \& King, 2019), the Ugandan government has strongly embraced women's entrepreneurship thus increasing high participation in the country. As a result of these alliances, Uganda has engaged in free market macroeconomic policies such as privatisation (Kingston, 2011; Heidhues \& Obare, 2011). However, contrary to what was expected by these measures, access to quality education which is a human right has become a business enterprise for those who can afford it (Nakulima, 2017), pushing girls into early work to get enough money for school fees. Entrepreneurship has become an alternative to formal education for girls and women who have left formal schools, given the urgent need to generate income for the livelihood of their households, families, and communities. This situation encourages survival driven businesses with limited education to achieve higher levels of success. Participants claimed: "Through my business, I have accumulated my own capital and I am soon getting enough money to go back and finish secondary school" (Participant 34) and "The economic conditions forced me to work because my children depended on it for their education" (Participant 55).

Students who persevered through the education system and achieved their university level of education subsequently faced high levels of youth unemployment (Draku, 2020; UBOS, 2018) where skills attained did not match the needs of the labour market to enable graduates easily obtain a well-paid and secure job. This has led to a mismatch of skills as those with university qualifications fail to get the rewards of a full formal education and decide to try their luck elsewhere, making formal school education a liability. In the long term, this trend negatively affects the desire of those pursuing a formal education since the labour market provides no hope for them for success. As a result, those that went to school and those that did not compete for the same resources irrespective of education status.

With a university degree, I got a job in a government organisation but it wasn't paying me as much as I had wanted. 350,000 Ushs (€85 approximately) for a graduate is not enough to live by. So, I organised some money from my friends and family and started a beverage store in the market which is giving me more money in comparison to my previous position. (Participant 84)

It's not to say that I wanted to be a food vendor in the market. I have vocational training in tailoring but in the beginning, I had no opportunity or resources to start tailoring. The capital I had was able to start me in the marketplace, nothing more. (Participant 38) 
Macroeconomic policies and market liberalisation: Greater education and greater economic opportunities for women?

Scholars such as Pamela Kahleen Koch (2011) and Winnie Busingye (2002) have evaluated the impact of market liberal policies such as privatisation (Nakulima, 2017) on women and gender relations within the household and have assessed their adoption in gender relations as a consequence of these policies. Among their results, they showed how the prices of important household items and food increased without a consequent increase in income. This situation resulted in the increase of hours spent in income-generating activities by women to maintain household consumption in order to afford decent livelihoods for their families. The participants claimed:

In Uganda today, having only one person earning for the household is difficult due to the high cost of living. So, I started my business because I wanted to support my husband who is a tradesman. (Participant 20)

I support my husband in Kamuli to take care of the children. If one of us has and the other does not have, the one who has helped the one who does not have. It's a win-win for us because we both work. (Participant 10)

\section{Challenges to women entrepreneurship and formal education}

While the macroeconomic policies on market and trade liberalisation adopted from the World Bank and the International Monetary Fund (1997) have encouraged female economic empowerment, they have also promoted harsh economic conditions in which women entrepreneurs have to struggle to attain quality education due to privatisation of education as well as compete for survival in entrepreneurship. The trade liberalisation policies such as currency devaluation (Kamugisha \& Assoua, 2020) and free foreign direct investment have been called the "blueprint" that developing economies must follow to overcome poverty and close the gender inequality gap (The World Bank, 2006). Additionally, they have been promoted as the way forward in which Uganda could achieve middle income status (Nyombi, 2016). However, they have favoured exports over import substitution, a total contradiction to women's entrepreneurial efforts.

The products that women entrepreneurs sell must compete with similar foreign products that flood the market, forcing them to charge higher prices in order to survive. Furthermore, fiscal favours such as tax holidays (Ntale, 2016) encourage direct foreign investments of large companies without leaving much room for small and medium-sized companies where female entrepreneurs predominate. These policies not only fail to improve the purchasing power of Ugandans to buy and build the country's domestic market, but also put great pressure on small and medium-sized business owners struggling for the survival of their businesses (Sandberg, 2017; Wedig \& Wiegratz, 2017).

Customers are becoming fewer and fewer. It is even making me consider leaving the business. There is a lot of competition from big supermarkets. Even my previous customers have left the city to go elsewhere because they felt it was not conducive for them to work here anymore. (Participant 8) 
There is too much competition these days with so many markets in town. Also, the prices keep fluctuating, today you may buy at a certain price, tomorrow at a different one and yet the customer wants a steady price to keep coming back. (Participant 1)

\section{CONCLUSIONS AND FURTHER RESEARCH}

Formal education and women entrepreneurship are two fundamental measures in the world of development for the promotion of women in Uganda. Their beginnings can be traced from pre-colonial periods and were promoted during independence to current times. It will be from the 1980's that both measures were connected to the adaptation of macroeconomic policies with the efforts of the government of Uganda to promote gender equality and women's economic empowerment.

However, there is a disproportion between both measures that contradict each other given the context of implementation in which they are inserted. The macroeconomic policies have negatively affected women. The high number of women that have a limited education represents one of the failures of the universal formal education system on one hand and privatisation of education on the other. Therefore, entrepreneurship is raised as an alternative for these women who struggle to sustain entrepreneurial ventures given competition tendencies arising from macroeconomic policies such as privatisation and foreign direct investment.

Formal education, therefore, does not equate to entrepreneurial success, provided that the majority of female entrepreneurs in the informal sector have abandoned formal education and started entrepreneurship as a way to satisfy immediate needs of their households and families to mitigate abject poverty. The difficulties of these businesswomen are multiple and important.

A multitude of questions arise from this study that may be answered in the further research on this topic such as: does formal education improve women's business success? If so, would sustainable business practices be possible under the patriarchal conditions imposed by macroeconomic policies? Not only would further research profoundly contribute to the discourse on women entrepreneurship and formal education in Uganda but it will also guide policy makers in identifying ways for business sustainability to be achieved.

\section{REFERENCES}

[1] Ahimbisibwe, A. (2019). Hopeful: A story of African childhood dreams and the relentless love and sacrifice of poor parents to give their children an education. Victoria: Friesen Press.

[2] Ajagbe, M. A., Kelechi, A. N., Kimuli, S. N. L., \& Cho, N. M. (2016). Problems and visions of entrepreneurship education in post primary schools. International Journal of Economics, Commerce and Management, 4(7), 633-650.

[3] Ajayl, J. F. (Ed.). (1998). UNESCO General History of Africa (Vol. 6). Africa in the nineteenth century until the 1880's. Oxford: Oxford-California Press. 
[4] Akyeampong, E. K., \& Fofack, H. (2014). The contribution of African women to economic growth and development in the precolonial and colonial periods: Historical perspectives and policy implications. Economic History of Developing Regions, 29(1), 42-73.

[5] Asare, R., Akuffobea, M., Quaye, W., \& Atta-Antwi, K. (2015). Characteristics of micro, small and medium enterprises in Ghana: Gender and implications for economic growth. African Journal of Science, Technology, Innovation and Development, 7(1), 26-35.

[6] Asongu, S. A., \& Odhiambo, N. M. (2018). Basic formal education quality, information technology, and inclusive human development in sub-Saharan Africa. Sustainable Development, 27(3), 419-428.

[7] Bamford. T. W. (1967). Rise of the public schools: A study of boys' public boarding schools in England and Wales from 1837 to the present day. London: Nelson.

[8] Bannink, F., Nalugya, R., \& van Hove, G. (2020). 'They give him a chance'- Parents' perspectives on disability and inclusive primary education in Uganda. International Journal of Disability, Development and Education 67(4), 357-375. doi:10.1080/1034912x.2019.1593326.

[9] Blaak, M., Openjuru, G. L., \& Zeleen, J. (2013). Non-formal vocational education in Uganda: Practical empowerment through a workable alternative. International Journal of Educational Development, 33(1), 88-97.

[10] Blau, R., \& Blau, P. (2019). Identity status, separation, and parent-adolescent relationships among boarding and day school students. Residential Treatment for Children $\mathcal{E}$ Youth, 38(2), 178-197. doi:10.1080/0886571X.2019.1692757.

[11] Boserup, E. (1970). Women's role in economic development. London: George Allen and Unwin Ltd.

[12] Busingye, W. (2002). The impact of structural adjustment programs on women, and gender relations in the household: The case of Kabale district. Kampala, Uganda: NURRU Publications.

[13] Carter, S. L., \& Shaw, E. (2006). Women's business ownership: Recent research and policy development. Retrieved July 2, 2021, from https:/ / strathprints.strath.ac.uk/8962/1/sbs_2006_report_ for_bis.pdf.

[14] Datzberger, S. (2018). Why education is not helping the poor. Findings from Uganda. World Development, 110, 124-139. doi:10.1016/j.worlddev.2018.05.022.

[15] Draku, F. (2020, December 18). Unemployment, poverty face Amuriat in Kampala. The Daily Monitor. Retrieved from https://www.monitor.co.ug/uganda/news/national/ unemployment-poverty-face-amuriat-in-kampala-3233026.

[16] Ejuu, G. (2012). Early childhood development policy advances in Uganda. Contemporary Issues in Early Childhood, 13(3), 248-255. doi:10.2304/ciec.2012.13.3.248.

[17] Etim, E. \& Iwu, C. G. (2019). A descriptive literature review of the continued marginalisation of female entrepreneurs in sub-Saharan Africa. International Journal of Gender Studies in Developing Societies, 3(1), 1-19. doi:10.1504/ijgsds.2019.096755.

[18] Ezati, B. A., Madanda, A., \& Ahikire, J. (2018). Improving learning in rural lower primary school through provision of informal ECD: Lessons from an NGO model in Uganda. Journal of Education and e-Learning Research, 5(1), 51-59. doi:10.20448/journal.509.2018.51.51.59.

[19] Fitzgerald, L. M. (2020). Weaving formal teacher education with non-formal environmental education: Making a career transition. In: C. U. Edge, A. Cameron-Standerford \& B. Bergh (Eds.), Textiles and tapestries: Self-study for envisioning new ways of knowing. EdTech Books.

[20] Forster, T., Kentikelenis, A. E., Reinsberg, B., Stubbs, T. H., \& King, L. P. (2019). How structural adjustment programs affect inequality: A disaggregated analysis of IMF conditionality, 1980-2014. Social Science Research, 80. 83-113. doi:10.1016/j.ssresearch.2019.01.001.

[21] Frankema, E. H. P. (2012). The origins of formal education in sub-Saharan Africa: Was British rule more benign? European Review of Economic History, 16(4), 335-355.

[22] Gavigan, S., Ciprikis, K., \& Cooney, T. (2020). The impact of entrepreneurship training on self-employment of rural female entrepreneurs in Uganda. Small Enterprise Research, 27(2), 180-194. doi.org/10.1080/13215906.2020.1769715.

[23] Green, E. (2010). Ethnicity and nationhood in precolonial Africa: The case of Buganda. Nationalism and Ethnic Politics, 16(1), 1-21. doi:10.1080/13537110903583310.

[24] Guma, P. K. (2015). Business in the urban informal economy: Barriers to women's entrepreneurship in Uganda. Journal of African Business, 16(3), 305-321. doi:10.1080/15228916.2015.10810 25. 
[25] Hansen, B. H., \& Twaddle, M. (2002). Christian missionaries and the state in the Third World. Ohio: Ohio University Press.

[26] Heidhues, F., \& Obare, G. (2011). Lessons from structural adjustment programmes and their effects in Africa. Quarterly Journal of International Agriculture, 50(1), 55-64. doi:10.22004/ ag.econ.155490.

[27] Humphris, J., Lles, L. (2013). Pre-colonial iron production in Great Lakes Africa: Recent research at UCL Institute of Archaeology. In: J. Humphris, \& T. Rehren. (Eds.), The world of iron (pp. 56-65). Archetype.

[28] International Monetary Fund. (1997). Annual report of the executive board for the financial year ended April 30, 1997. Retrieved August 1, 2021, from https:/ /www.imf.org/en/Publications/ International-Monetary-Fund-Annual-Report-1997-2309.

[29] Jones, S. K. (2011). Girls' secondary education in Uganda: Assessing policy within the women's empowerment framework. Gender and Education, 23(4), 385-413. doi.org/10.1080/09540 253.2010.499854.

[30] Kadaga, R. (2013). Women's political leadership in East Africa with specific reference to Uganda. In: Commonwealth Local Governance Forum (Ed.). Commonwealth governance handbook 2013/2014 (pp. 32-36). London: Commonwealth Secretariat.

[31] Kamugisha, G., \& Assoua, J. E. (2020). Effects of a devaluation on trade balance in Uganda: An ARDL co-integration approach. International Journal of Economics and Finance, 12(7), 42-53. doi:10.5539/ijef.v12n7p42.

[32] Kayongo, E., Kawooya, I., \& Mijumbi-Deve, R. (2019). The causes of school dropout at the transition between primary to secondary school and possible control measures. Retrieved August 10, 2021, from https://acres.or.ug/2020/01/ final-causes-of-school-drop-out.pdf.

[33] Khadidja, D. (2014). Western Education in Uganda 1878-1939 [Unpublished master's thesis]. University of Oran.

[34] Kikooma, J. (2012). Gender and entrepreneurship in Uganda: Women manoeuvring economic space. In: T. Burger-Helmchen (Ed.), Entrepreneurship, gender, geographies and social context (pp. 2-30). Intech Open. doi:10.5772/35573.

[35] Kingston, K. G. (2011). The impacts of the World Bank and IMF structural adjustment programmes on Africa: The case study of Cote d'Ivoire, Senegal, Uganda, and Zimbabwe. Sacha Journal of Policy and Strategic Studies, 1(2), 110-130.

[36] Kislova, A. (2020). Role of informal education supported by social networks and internet platforms in the development of the anti-corruption movement in Russia. In. M. Brown, M. Nic Giolla Mhichil, E. Beirne, \& E. Costello (Eds.), Proceedings of the 2019 ICDE World Conference on Online Learning (Vol. 1, pp. 501-511). Dublin: Dublin City University. doi:org/10.5281/ zenodo.3804014.

[37] Koch, P. K. (2011). Primary commodity dependence and agricultural diversification: The role of organic agriculture in trade and the implications for food security in sub-Saharan Africa [Unpublished master's thesis]. University of KwaZulu-Natal.

[38] Kolodych, D., \& Zarzycka-Dertli, J. E. (2020). Development features of emotional intelligence in the conditions of informal education (cross cultural aspect). Socialisation \& Human Development: International Scientific Journal, 2(1), 5-13. doi:10.37096/shd/sj-20-1.1-0001.

[39] Komakech, A. R. (2015). School Attendance is a pre-requisite for student academic performance in universal secondary education schools. Journal of Social Science for Policy Implications, 3(1), 33-57. doi:10.15640/jsspi.v3n1a3.

[40] Kyomuhendo, G. B. \& McIntosh, M. K. (2006). Women, work and domestic virtue in Uganda, 1900-2003. Oxford: James Currey.

[41] MasterCard Index. (2018, March 7). Women in charge: MasterCard index reveals how countries are progressing to empower women entrepreneurs. [Press release]. Retrieved August 7, 2021, from https://newsroom.mastercard.com/press-releases/.

[42] Matovu, M. (2016). Restoring African women to history: A history of pre-colonial East African Baganda women [Unpublished bachelor's thesis]. California Polytechnic State University.

[43] Ministry of Education and Sports (2015). Education Sector Strategic Plan 2004-2015. Retrieved September 21, 2020, from http://planipolis.iiep.unesco.org/sites/planipolis/files/ressources/uganda_essp_2004_2015.pdf. 
[44] Ministry of Education and Sports. (2013). National Strategy for Girls' Education (NSGE). Retrieved August 10, 2021, from https://scorecard.prb.org/2018/05/National-Strategy-forGirls-Education-in-Uganda-2015-2019.pdf.

[45] Mockler-Ferryman, A. F. (1903). Christianity in Uganda. African Affairs, 2(7), 276-291. doi:10.1093/oxfordjournal.afraf.a093207.

[46] Monteith, W., \& Camfield, L. (2019). Business as family, family as business: Female entrepreneurship in Kampala, Uganda. Geoforum, 101. 111-121. doi:10.1016/j.geoforum.2019.03.003.

[47] Musisi, N. B. (1993). The environment, gender of unequal relations: A historical perspective. Canadian Woman Studies, 13(3), 54-59.

[48] Nakulima, S. (2017). Privatisation in education and discrimination: Its impact on the right to education in Uganda. ESR Review: Economic and Social Rights in South Africa, 18(1), 10-13.

[49] Namukwaya, V. A., \& Kibirige, I. (2019). Parents' perceptions of universal primary education in Kotido district, Uganda. Issues in Educational Research, 29(2), 502-518.

[50] Nangoli, S. Turinawe., D. Kituyi, G. Kusemererwa, C., \& Jaaza, M. (2013). Towards enhancing business survival and growth rates in LDCs: An exploratory study of the drivers of business failure among SMES in Kampala-Uganda. International Journal of Humanities and Social Science, 3(8), 284-291. doi:10.1.1.1049.9667.

[51] National Curriculum Development Centre (2014). Entrepreneurship education in Uganda. Retrieved August 2, 2021, from https://www.unido.org/sites/default/files/2014-12/ECP_ Conf_Session_I_Uganda_11Nov2014_0.pdf.

[52] National Curriculum Development Centre (2020). Curriculum. Retrieved August 2, 2021, from https://www.ncdc.go.ug/curriculum.

[53] National Development Plan (2015). Uganda vision 2040: A transformed Ugandan society from a peasant to a modern and prosperous country within 30 years: Strengthening Uganda's competitiveness for sustainable wealth creation, employment and inclusive growth. Retrieved August 2, 2021, from http://npa.go.ug/ndpii-final.pdf.

[54] Nayenga, P. F. B (1981). Commercial cotton growing in Busoga district, Uganda, 1905-1923. African Economic History, 10. 175-195. doi:10.2307/3601299.

[55] Ninsiima. R, \& Abonit. H. (2013, February 13). Senior One fees rise. The Observer. Retrieved from https:// www.observer.ug/education/85-education/23500-senior-one-fees-rise.

[56] Noguchi, F. (2018). Critical reflections on the UNDESD: From the perspectives of informal education in a community development context. Journal of Education for Sustainable Development, 11(2), 141-151. doi:10.1177/0973408218763468.

[57] Ntale, A. (2019). The state of the economy for Ugandan women. Retrieved August 5, 2021, from https:/ / www.akinamamawaafrika.org/state-of-ugandas-economy-for-women/.

[58] Nyombi, H. (2016). Evolution of Uganda's economy and the road to middle income status. Retrieved August 3, 2021, from. https://ugandamediacentre/2016/11/24/ evolution-of-ugandas-economy-and-the-road-to-middle-income-status/.

[59] Odaga, G. (2020). Gender in Uganda's tertiary distribution. Journal of Sciences \& Humanities Open, 2(1). doi:10.1016/j.ssaho.2020.100023.

[60] Oded, A. (1974). Islam in Uganda: Islamisation through a centralised state in pre-colonial Africa. New York: Halsted Press.

[61] Okoth, C. (2019, August 19). Entrepreneurship to be made compulsory for S1 and S2. The New Vision. Retrieved from https://www.newvision.co.ug/news/entrepreneurship-compulsory-s1.

[62] Orobia, L. A., Tusiime, I., Mwesigwa, R., \& Ssekiziyivu, B. (2020). Entrepreneurial framework conditions and business sustainability among the youth and women entrepreneurs. Asia Pacific Journal of Innovation and Entrepreneurship, 14(1), 60-75. doi:10.1108/ APJIE-07-2019-0059.

[63] Panda, S. (2018). Constraints faced by women entrepreneurs in developing countries: review and ranking. Journal of Gender in Management, 33(4), 315-331.

[64] Ratten, V., \& Jones, P. (2018). Bringing Africa into entrepreneurship research. In: P. L. Dana, V. Ratten, \& B. Q. Honyenuga (Eds.), African entrepreneurship (pp. 9-27). London, United Kingdom: Palgrave Macmillan.

[65] Rogers, B. (1980). The domestication of women: Discrimination in developing societies. London: Kogan.

[66] Sandberg, E. (2017). Challenges to African entrepreneurship in the $21^{\text {st }}$ century. In: D. Opoku \& E. Sandberg (Eds.), Challenges to African entrepreneurship in the $21^{\text {st }}$ century (pp. 179-202). London, United Kingdom: Palgrave Macmillan. 
[67] Scanlon, D. (1964). Education in Uganda. Columbia: Columbia University.

[68] Sejjaaka, S. K., Mindra, R., \& Nsereko, I. (2015). Leadership traits and business sustainability in Ugandan SMEs: A qualitative analysis. International Journal of Management Science and Business Administration, 1(6), 42-57.

[69] Sheldon, K. (2015). African women: Early history to the 21st century. Indiana: Indiana University Press.

[70] Sobehart, H. C. (2009). Women leading across the continents: Sharing the spirit, fanning flame. London: Dequsure University.

[71] Ssekamwa, J, C. (1997). History and development of education in Uganda. Kampala: Fountain Publishers.

[72] Ssempebwa, J. (2008). Graduate unemployment in Uganda: Socio-economic factors exonerating university training. Retrieved August 6, 2021, from https://www.researchgate.net/publication/graduate_unemployment_in_uganda_socio-_economic_factors_exonerating_university_training.

[73] Stonehouse, A. (2012). Peripheral identities in an African State: A history of ethnicity in the kingdom of Buganda since 1884. Retrieved August 12, 2021, from https://etheses.whiterose. ac.uk/12751/1/590282.pdf.

[74] Struwig, F. W., Krüger, J. \& Nuwagaba, G. (2019). The influence of the business environment on the growth of informal businesses in Uganda. Southern African Journal of Entrepreneurship and Small Business Management, 11(1). doi:10.4102/sajesbm.v11i1.200.

[75] Tushabomwe-Kazooba, C. (2006). Causes of small business failure in Uganda: A case study from Bushenyi and Mbarara Towns. African Studies Quarterly, 8(4), 27-35.

[76] Twaddle, M. (1974). Ganda receptivity to change. Journal of African History, 15(2), 303-315. doi:10.1017/S0021853700000906.

[77] Uganda Bureau of Statistics (2017). The National Population and Housing Census 2014. Retrieved August 10, 2021, from https://www.ubos.org/educationmonographreportfinal08-12-2017. pdf.

[78] Uganda Bureau of Statistics (2018). National Labour Force Survey 2016/2017. Retrieved on August 10, 2021, from https://www.ubos.org/wp102018Reportnationallabourforcesurvey201617.pdf.

[79] United Nations Development Programme (2004). Human development report. Retrieved August 5, 2021, from http://hdr.undp.org/hdr_2004_complete.pdf.

[80] United Nations Educational, Scientific and Cultural Organisation (2019). Secondary education. Retrieved August 5, 2021, from https://data.unicef.org/topic/education/secondaryeducation/.

[81] United Nations International Children's Emergency Fund (2019). Secondary education. Retrieved August 4, 2021, from https:// data.unicef.org/topic/education/secondary-education/.

[82] United Nations (2000). United Nations Millennium Declaration. Retrieved August 12, 2021, from https://undocs.org/a/res/55/2.

[83] Wedig, K., \& Wiegratz, J. (2017). Neoliberalism and the revival of agricultural cooperatives: The case of the coffee sector in Uganda. Journal of Agrarian Change, 18(2), 348-369. doi:10.1111/ joac.12221.

[84] Wodon, Q., Nguyen, M. C., \& Tsimpo, C. (2016) Child marriage, education, and agency in Uganda. Feminist Economics, 22(1), 54-79. doi:10.1080/13545701.2015.1102020.

[85] The World Bank (2006). World development report: Equity and development (Report No. 32204). Retrieved August 11, 2021, from https:// documents1.worldbank.org/worlddevelopmentreport2006.pdf.

[86] Zembylas, M. (2001). Jean-Francoise Lyotard 1924-98. In L. Bresler, D. Cooper \& J. Palmer (Eds.), Fifty modern thinkers on education: From Piaget to the present (pp. 148-154). London, United Kingdom: Routledge.

[87] zu Selhausen, F. P. M. (2015). Women's empowerment in Uganda: Colonial roots and contemporary efforts, 1894-2012 [Unpublished doctoral dissertation]. Utrecht University. 